University of Nebraska - Lincoln

DigitalCommons@University of Nebraska - Lincoln

Papers in the Earth and Atmospheric Sciences

Earth and Atmospheric Sciences, Department

\title{
Chloride and the Environmental Isotopes as the Indicators of the Groundwater Recharge in the Gobi Desert, Northwest China
}

\author{
J. Z. Ma \\ Lanzhou University \\ Z. Ding \\ Lanzhou University \\ John B. Gates \\ University of Nebraska-Lincoln, jgates2@unl.edu \\ Y. Su \\ Cold and Arid Regions Environmental and Engineering Research Institute
}

Follow this and additional works at: https://digitalcommons.unl.edu/geosciencefacpub

Part of the Earth Sciences Commons

Ma, J. Z.; Ding, Z.; Gates, John B.; and Su, Y., "Chloride and the Environmental Isotopes as the Indicators of the Groundwater Recharge in the Gobi Desert, Northwest China" (2008). Papers in the Earth and Atmospheric Sciences. 269.

https://digitalcommons.unl.edu/geosciencefacpub/269

This Article is brought to you for free and open access by the Earth and Atmospheric Sciences, Department of at DigitalCommons@University of Nebraska - Lincoln. It has been accepted for inclusion in Papers in the Earth and Atmospheric Sciences by an authorized administrator of DigitalCommons@University of Nebraska - Lincoln. 
Published in Environmental Geology 55 (2008), pp.1407-1419; doi: 10.1007/s00254-007-1091-1.

Copyright (c) 2007 Springer-Verlag. Used by permission.

Submitted June 26, 2007; accepted October 11, 2007; published online October 30, 2007.

\title{
Chloride and the Environmental Isotopes as the Indicators of the Groundwater Recharge in the Gobi Desert, Northwest China
}

\author{
J. Z. Ma, ${ }^{1}$ Z. Ding, ${ }^{1}$ John B. Gates, ${ }^{2}$ and Y. Su ${ }^{3}$ \\ 1. Key Laboratory of Western China's Environmental System (Ministry of Education), Lanzhou University, \\ Lanzhou, China; emails: ding_zhenyu@126.com, jzma@lzu.edu.cn \\ 2. University of Nebraska-Lincoln, formerly of the Oxford Centre for Water Research, Oxford University, Ox- \\ ford, UK; email: jgates2@unl.edu \\ 3. Cold and Arid Regions Environmental and Engineering Research Institute, CAS, Lanzhou 730000, China \\ Corresponding author - Z. Ding
}

\begin{abstract}
The long term recharge in Gobi Desert from Hexi Corridor to Inner Mongolia Plateau was estimated to Be $1 \mathrm{~mm}$ year ${ }^{-1}$ by using the chloride mass balance method from one unsaturated zone profile, which shows that no effective modern recharge is taking place. A good rainfall database from Zhangye provides definition of the stable isotopic composition of modern rainfall. The signature of groundwater from the late Pleistocene differs markedly from that of the Holocene, shown clearly by the compositions of $-10.5 \%$ o $\delta^{18} \mathrm{O}$ as compared with values of $-7 \%$ o at the present day. It is apparent that the groundwaters in the Minqin Basin, Ejina Basin and feeding the lake system of the Badain Jaran are part of a regional flow network related to a wetter past climate as source of recharge. The recharge source in the past and to a limited extent in the more arid conditions of the present day included the foothills of the mountains of the Tibetan Plateau. The tritium age determinations accurate to the year are impossible and of no meaning to groundwater studies. A tritium value in the groundwater means multiple recharge ages in this region.
\end{abstract}

Keywords: Groundwater recharge, Geochemistry, Environmental isotope, Hexi Corridor, Inner Mongolia Plateau

\section{Introduction}

Arid zones in the northwest China refer to the inland dryland north of $35 \mathrm{~N}$ and west of $106 \mathrm{E}$, including the whole Xinjiang Autonomous Region, Hexi Corridor in Gansu Province and the area west of Helan Mountains in Inner Mongolia. It is one of the driest zones in the world. The surface water resources and groundwater only account for 3.3 and $5.5 \%$ of national total whilst the area occupies $24.5 \%$ of Chinese total land (Shi and Zhang 1995). Mean annual runoff per kilometer in China is $1,880 \mathrm{~m}^{3}$ whilst in the northwest China the per capita runoff is $35.2 \%$ and mean annual runoff is $43.1 \%$ of the country's average level. The total water shortage in the arid NW China is predicted to be about 15 billion cubic meters by the beginning of the 21st century. This will greatly influence the water supply both for drinking and irrigation of the region (Feng et al. 1997). Over the past decades, the Chinese government and scientists have carried out much research and obtained great achievement including in understanding mechanism of groundwater recharge, movement and discharge; numerical modeling of groundwater flow; groundwater management model; application of isotope technology; moisture movement in unsaturated zone and the groundwater exploitation and its effect on the fragile ecology (Wu 1999). However, the previous methods of groundwater research are mainly based on water balance, which are inadequate for low rainfall areas with high evapotranspiration (Allison et al. 1994; Gee et al. 1994). Research interests have been focused on aspects such as utilization survey, evolutionary prediction, re- 
serve estimation and systematic assessment of natural water resources. Some reasonable allocation and utilization plans have been proposed. Study of the hydrochemistry (especially isotopic geochemistry) of water resources is rather sparse and past work on the arid area has dealt largely with the chemical properties of the water, although there are several investigations on the interaction and mechanism between surface water, groundwater and rock in particular areas in recent years (Shi et al. 2001; Feng et al. 2004; Zhang et al. 2005; Edmunds et al. 2006). However, it is short of the regional understand of the groundwater recharge and chemical evolution, the volume of water available in the aquifer is not known and its rate of recharge, if any, is very uncertain. The present study focus on the issue as a part of an interdisciplinary study to look at the palaeoecology, climatic change and social consequences in the context from Hexi Corridor to Inner Mongolia Plateau as the typical areas of arid NW China. The scope of the present study and the main objective is to estimation of natural groundwater recharge to aquifers, and understand the groundwater evolution and identify chemical changes taking place along the original direction of groundwater flow towards the terminal lake of Inland river basins, and the specific targets are to (1) use the geochemical and isotopic technology to determine the present day recharge rates from unsaturated zone of desert; (2) determine which are the predominant geochemical process taking place along the inferred horizontal groundwater flow line and (3) use stable isotopes and tritium to determine the evolution and the age of the groundwater under the natural conditions during the recent geological past. This approach has been used successfully in other semi-arid regions underlain by large freshwater resources (Edmunds et al. 2003). Similar comprehensive approaches to groundwater understanding combining unsaturated zone chemistry and isotopic indicators are relatively few in China but palaeoclimatic studies combined with chemistry are beginning to show that basins in northern China were recharged under wetter conditions in the past and therefore non-renewable (Chen et al. 2003). Improved understanding of the resources therefore is fundamental to many important decisions that will need to be made in China (as in other arid regions), in relation to demographic change and the reform of agricultural practices (Ma et al. 2005).

\section{The study area and geological setting}

The study area includes the Shiyang River Basin, Heihe River Basin and Baddain Jaran Desert, which is summarized in the Figure 1. Heihe River Basin, with 821 $\mathrm{km}$ in length and cover $13 \times 10^{4} \mathrm{~km}^{2}$ in area, is one of the greatest inland rivers in China. The total runoff of Heihe River coming from Qilian Mountain outlets is about $37.55 \times 10^{8} \mathrm{~m}^{3}$ yearly. The water resources were developed dramatically and water system changed markedly in the recent years. A period of more than 200 days with no continuous flow in the Ejina was a cause for great concern in Gansu and Inner Mongolia which rely on the diversion from the Heihe River for irrigation and drinking water supply. The Shiyang River Basin, located in the east of Hexi Corridor, is the link and ecotone of loess plateau, Tibetan Plateau and Mongolia Plateau. The catchment covers an area of $41.6 \times 10^{3} \mathrm{~km}^{2}$ and total length is merely $300 \mathrm{~km}$. The total surface runoff flowing out of the mountain reaches is about 1.58 billion $\mathrm{m}^{3}$ of eight tributaries. These rivers recombine in $\mathrm{Wu}-$ wei Basin discharging to the Minqin Basin through adjusting of Hongyashan reservior. The Minqin Basin has recently been the focus of attention due to increasing stress on its water resources and environmental degradation and the Prime Minister has indicated a national priority to rehabilitate this important and historic area.

The Hexi Corridor, located on the northeast margin of the Qinghai-Tibet Plateau, is a Cenozoic foreland basin system. The subduction of the Indian Plate under the Eurasian Plate caused the Qinghai-Tibet Plateau to become uplifted and pushed to the north (Molner and Tapponnier 1975; Harrison et al. 1992). The fault zone at the northeast front of the Qilian Mountain, trending WNW and dipping to SSW, is an active reverse fault zone. The active faults in the Hexi Corridor are mainly reverse faults. The faults trending $\mathrm{WNW}$ are dominated by sinistral slip and the faults trending NNW with dextral slip. This indicates a NE-SW compression in the Hexi Corridor. The uplift of the Qilian geosyncline occurred from the end of the Palaeozoic throughout the whole Mesozoic era, and created the embryonic form of the Hexi Corridor. The uplift of the Qilian geosyncline occurred from the end of the Palaeozoic throughout the whole Mesozoic era, and created the embryonic form of the Hexi Corridor. This was followed by a complex tectonic stage when the structural zones, Longshou-hongya Mountain, Heli-Mazong Mountain were formed in the middle of the Hexi Corridor; cutting the whole Corridor into two parts, that is the southern basins and the northern one. From east to west in the southern part, three Tertiary uplifts, the Dahuang Mountains, Yumu Mountains and Wenshu Mountains, separate the Hexi Corridor into the Wuwei, Zhangye, Jiuquan and Yumen Basins (Figure 1). From the late Tertiary, especially from the end of the Pliocene and the beginning of the early Pleistocene, the surrounding Tibetan mountains began to rise up rapidly ( $\mathrm{Li}$ et al. 1979) and the basins subsided further. At the same time the intensive denudation and erosion from the mountains led to significant 


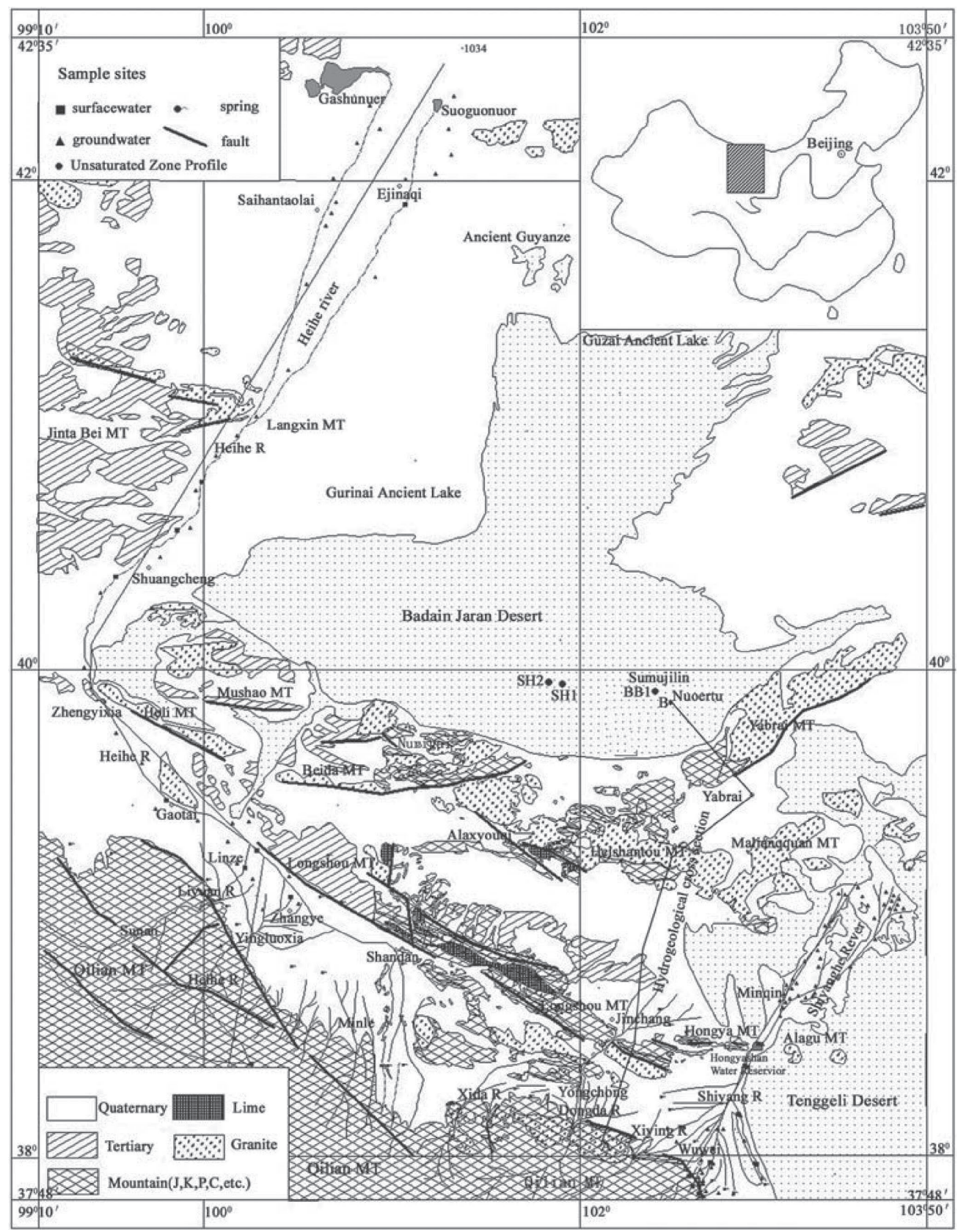

Figure 1. The study area and the location of the Shiyang River, Heihe River and Baddain Jaran Desert

transfer of clastic material to the basin depressions. This formation of thick Quaternary diluvial and alluvial sediments, and some aeolian and lacustrine deposits, led to the formation of the main aquifers. Huge loosen Quaternary sediments with maximum over $1,000 \mathrm{~m}$ had been deposited during geological history in the fore depression, which provides a large space for groundwater reserve and transport. The Quaternary basins can be divide into geomorphologic units such as piedmont alluvial plain, alluvial lacustrine plain and desert; and the sedimental compositions gradually turn from large pore gravel to medium and fine sand and silt respectively. The active reverse faults zone and derivative Cenozoic fold along the North piedmont Qilian Mountains resulted in very complex groundwater hydraulic contact between the Mountain and Plain (Ding et al. 2002). In the eastern part there occurs blind imbricate fault zone of 2-6 km wider and there is very thin Quaternary deposit on the fault bench which is recharged by the rainfall and infiltration water. There is a water table difference of 4-20 m between upper wall and lying wall of the fault bench and there is a water difference of 80-200 m between fault bench and Quaternary aquifer in the Plain (A in Figure 2). In the western Heihe River there developed a fault mylonite zone of $100-400$ m wider, which is impermeable and lead to a subsurface linn of 120-180 m 

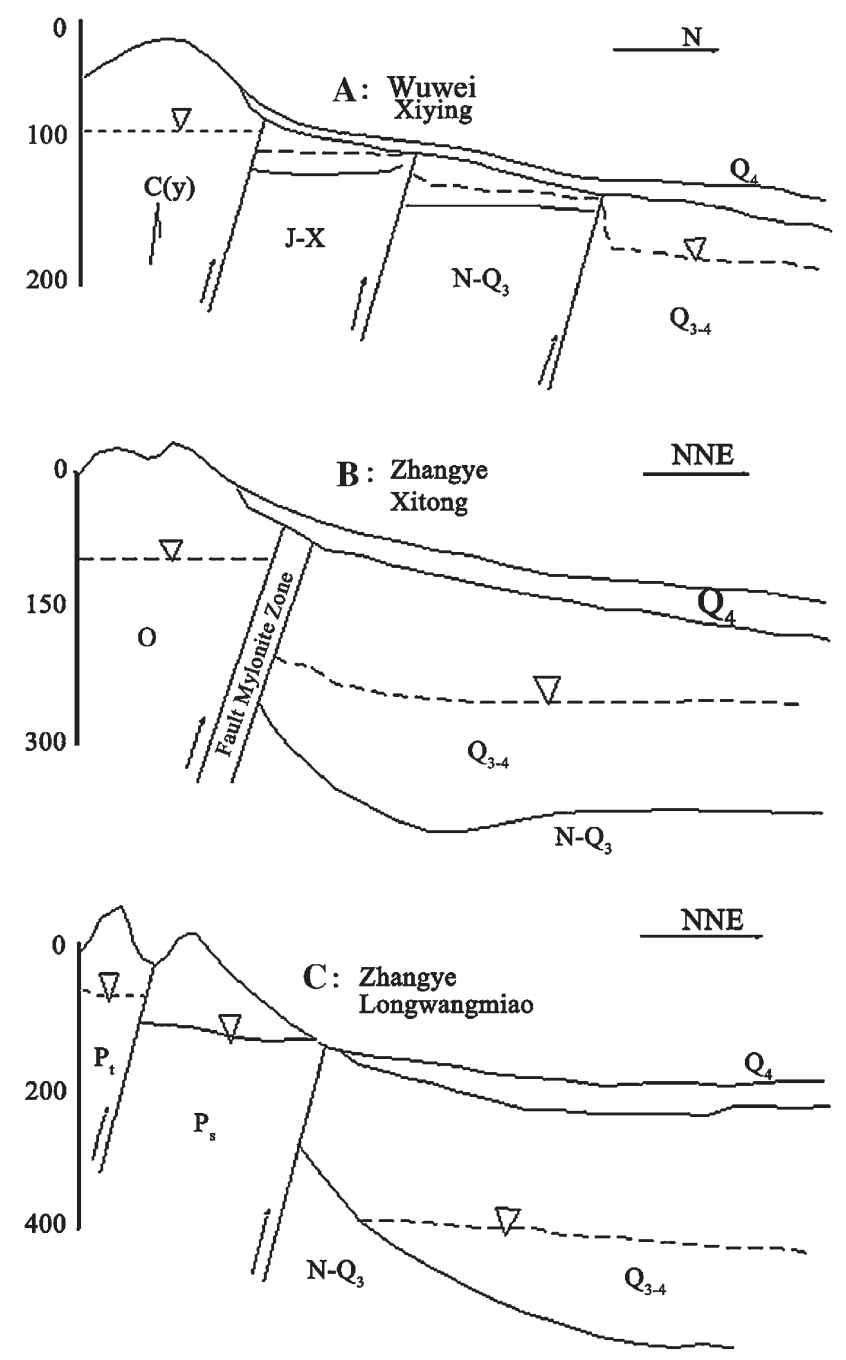

Figure 2. The simple hydrological sections showing the hydraulic contact relationship between the Qilian Mountain and Quaternary aquifer in Hexi Corridor (after Ding et al. 2002)

difference between Mountain and plain aquifer (B in Figure 2). There partially occurs no fault mylonite zone and the Quaternary aquifer contact with Mountain directly through fault. The groundwater flow from the mountain area is absolutely obstruct and distribute a lot of springs along the upper wall of the fault, and the groundwater table difference amount to $200 \mathrm{~m}$ between the Mountain and Plain (C in Figure 2). However, the Quaternary aquifers are all closely connected with streams originated in the Qilian Mountains which discharge the tectonic fracture groundwater. These streams pass through two or three basins and flow into the terminal lakes once the runoff formed by melting ice-snow, precipitation and the springs in the mountains. There is a complex transformation relation between the surface and groundwater. More than $80 \%$ of surface water in the piedmont fan seeping down to the aquifer and then in the fine earthy plain belt, about $40 \%$ of groundwater discharge to feed the spring and river. Such transformation process of surface water to groundwater and then to surface water again in the quaternary basins maybe repeated many times because of the existence of tectonic uplifted zone in the middle of the Hexi Corridor such as Longshou-hongya Mountain, Heli-Mazong Mountain and some small hills, which led to groundwater barely crosses the fracture from south basin to recharge the north basins. The relation can be seen clearly from the hydrological section from Qilian Mountain northward to Baddain Jaran Desert (Figure 3). Human activities, such as pumping groundwater, irrigating land and constructing dams, make the exchange between surface water and groundwater more complex ( $\mathrm{Li}$ and Feng 1997; Ma et al. 2005).

The Badain Jaran desert is the second largest desert in China with an area of $49,200 \mathrm{~km}^{2}$, and is characterized of more than $50 \%$ of the area distributed densely huge megadunes with a relative height of 200-300 m (Hofmann 1996). Among the highest megadunes in the SE part of the desert, more than 100 lakes of different size are concentrated within an area of approximately $4,000 \mathrm{~km}^{2}$. A strong seasonal East Asian monsoonal regime, which reaches the margins of the desert in summertime, is responsible for rainfall from July to September, while in the wintertime, cold and dry continental air masses with temperatures below 0 frequently influence the area (Zhang and Lin 1992). It tectonically belongs to the depression basin of Alxa platform, being a part from Alxa upwarping through Zongnaishan fault. The Jurassic system, Cretaceous system and Tertiary Stratum are emergence along the fringe of the basin, whilst the center of the Basin is occupied with the Quaternary Sediment. In the Palaeozoic era the region maybe contact with the Alxa upwarping and form the integrated block. Hercynian movement led to fold and uplift, and at the same time coming forth the fault in the uplifted block. The fault revived in the period of Yenshan movement, which led to the peripheral mountain uplifted and the basin settled, and then deposited the Jurassic and Cretaceous rock. In the Cenozoic era, the depression continually expanded resulted from the Himalaya movement, and deposited the Tertiary red fragment rock. The new tectonic movement led to the whole block elevates and produced the fault terrace in the basin Quaternary system in Badain Jaran region is mainly the terrestrial faces sediment of a suit of gray-yellowish, loose or consolidating state. The Holocene eolian sediments are the major phreatic aquifer in the Badain Jaran Desert. The groundwaters feeding lakes in the southern desert have a neutral $\mathrm{pH}$ and a total mineralization in the range 720-1,180 $\mathrm{mg} \mathrm{l}^{-1}$ which is only slightly less than the lakes (Ma and Edmunds 2006). From other studies, the lakes in the southern Badain Jaran Desert show a full range of salinities (Hofmann 1996). 


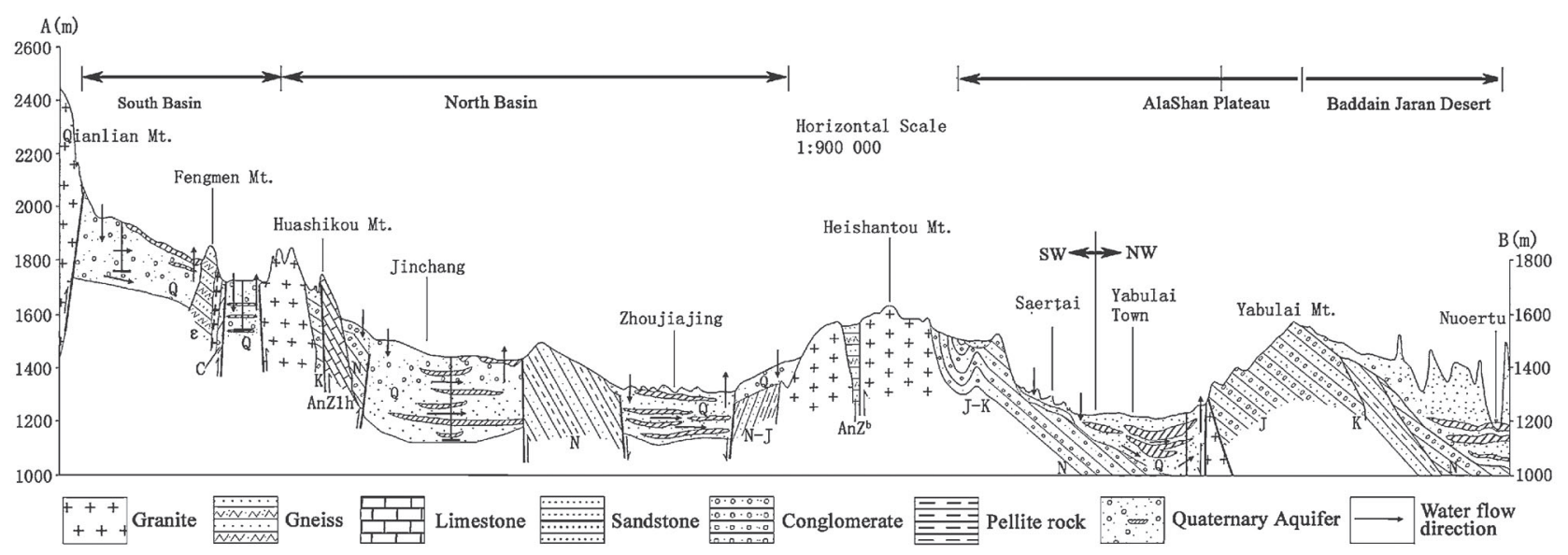

Figure 3. The hydrogeological cross section from Qilian Mountain northward to the Hexi Corridor and Baddain Jaran Desert showing the relation of groundwater in different basins

\section{Methods}

Field work took place during the summer of 2004 during which groundwater and surface water samples in the Shiyang River Basin were taken for isotopic and chemical analysis. Following preliminary interpretation of these data a further sampling campaign was conducted in 2005 during which, the groundwater and surface samples from Heihe River Basin were collected. On site analysis of water samples included temperature, specific electrical conductance, total alkalinity (as $\mathrm{HCO}_{3}^{-}$ ) by titration and $\mathrm{pH}$. Major anions $\left(\mathrm{Cl}^{-}, \mathrm{SO}_{4}^{2-} \mathrm{NO}_{3}-\mathrm{N}, \mathrm{Br}\right.$ and $\mathrm{F}$ ) were analyzed by ion chromatography (Dionex ICS-2500) in the Key Laboratory of West China's Environmental System (MOE), Lanzhou University. Filtered and acidified samples were analyzed for major cations $\left(\mathrm{Na}^{+}, \mathrm{K}^{+}, \mathrm{Ca}^{2+}, \mathrm{Mg}^{2+}\right)$ by ICP-OES (ARL3400C) and trace elements by ICP-MS (VG PQ Ex-Cell). Samples for stable isotope analysis $\left({ }^{18} \mathrm{O},{ }^{2} \mathrm{H}\right)$ were measured by isotope ratio mass spectrometry (MAT 253) at the British Geological Survey Isotope Laboratory in Wallingford, UK. Calibrations for cation analyzes were performed using appropriately diluted standards and both laboratory and international reference materials were used as checks for accuracy. Instrumental drift during ICP-MS analysis was corrected using In and Pt internal standards. Determining the ionic balance provided an internal check on the quality of the data, the balance lay below $\pm 6 \%$ except for seven samples of groundwater in Heihe River Basin. Precision of measurement for stable isotopes was $\pm 0.1 \%$ o for $\delta^{18} \mathrm{O}$, and $\pm 2 \%$ o for $\delta^{2} \mathrm{H}$. The three unsaturated zone profiles were taken by hollow stem hand augur in the center of the Badain Jaran Desert for investigation of the moisture content and unsaturated zone chemistry to obtain data on modern recharge rates and to determine recharge history. Two of them, SH1 (to a depth of $10 \mathrm{~m}$ and arrival to groundwater ta- ble) and SH2 (20 m deep) around the Suhete Lake, were obtained in the October, 2004, and the other one, BB1 $(20 \mathrm{~m})$ in the Badain Jilinmiao was obtained in the June, 2005. Samples were homogenized over sample intervals of $25 \mathrm{~cm}$. To a $50 \mathrm{~g}$ sand sample $30 \mathrm{ml}$ of distilled deionized water was added to elute the solutes (for $\mathrm{Cl}$ ). Estimations of groundwater recharge were carried out using the chloride mass balance (CMB) technique (Allison and Hughes 1978; Edmunds et al. 1988). The recharge history may be determined using the cumulative $\mathrm{Cl}$ in the profile as an indicator of age, based on similar assumptions as above, using the $\mathrm{Cl}$ mass flux to the unsaturated zone and knowing the volumetric moisture contents. The age or residence time represented by $\mathrm{Cl}$ can be evaluated by dividing the cumulative total mass of chloride from the surface to that depth by the annual $\mathrm{Cl}$ input (Tyler et al. 1996).

\section{Results and discussion}

Recharge estimation from unsaturated zone profiles

The presence of several peaks and troughs in the chloride profiles must be proportional to the amount of evapotranspiration and hence to oscillating recharge rates and past climate. In the Badain Jaran Desert, anthropogenic effects and internal contributions of $\mathrm{Cl}$ are non-existent so that the averaged profile $\mathrm{Cl}$ values provide a long term record of recharge rate over the time interval reflected by the profile. In these fine-grained sands piston flow of moisture takes place in the unsaturated zone and as discussed by Cook et al. (1992) a record of recharge history is also preserved. The chloride results obtained by elutriation for each hole are presented in Figure 4 as a function of depth compared with the moisture content. The oscillations of chloride show 

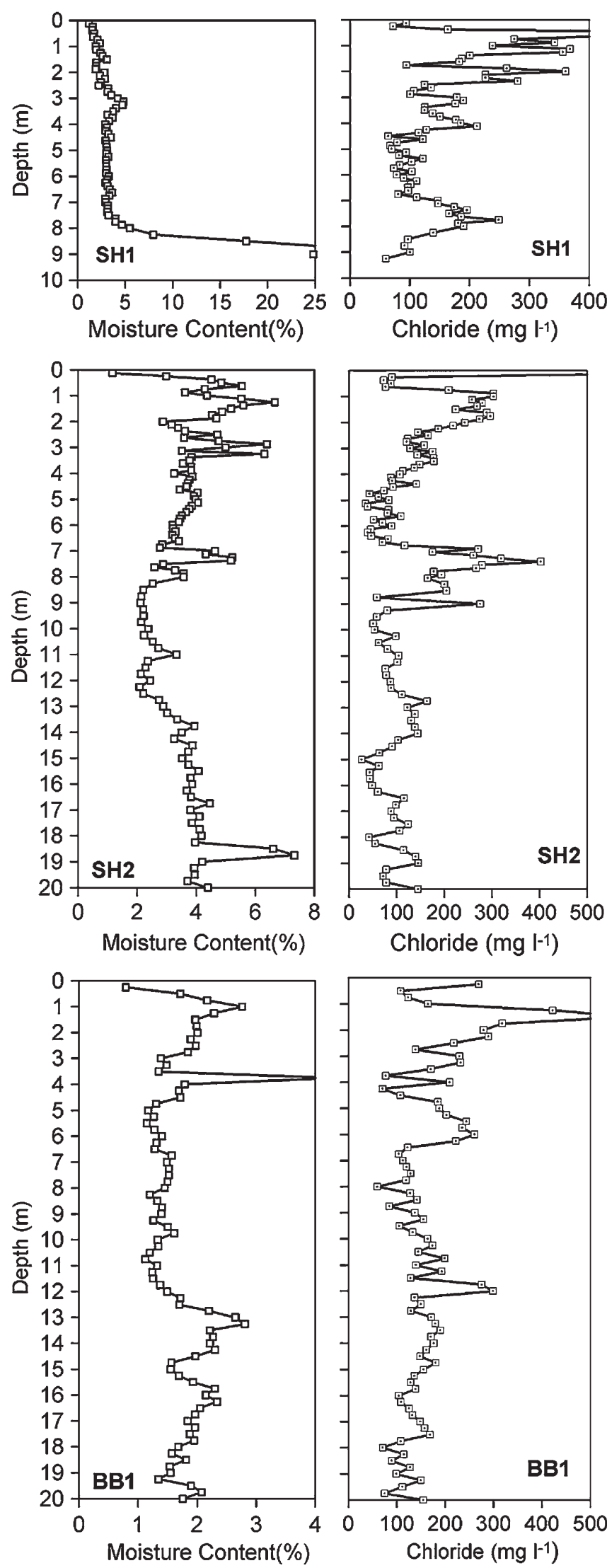

Figure 4. The $\mathrm{Cl}$ concentration profiles at the Badain Jilinmiao and Suhete shown as the function of depth together with the moisture content (MC) that the recharge rate has not been constant. Chloride concentration has a mean value of $165 \mathrm{mg} \mathrm{l}^{-1}$ in the BB1 profile, with ranging from $59 \mathrm{mg} \mathrm{l}^{-1}$ to $581 \mathrm{mg} \mathrm{l}^{-1}$. The average chloride in $\mathrm{SH} 1$ and $\mathrm{SH} 2$ profiles is of $120 \mathrm{mg}$ $\mathrm{l}^{-1}$ and $127 \mathrm{mg} \mathrm{l}^{-1}$, respectively, ranging from $26 \mathrm{mg} \mathrm{l}^{-1}$ to $643 \mathrm{mg} \mathrm{l}^{-1}$. Besides the high chloride value in the upper $1.5 \mathrm{~m}$, there is also show the very high chloride concentration between depths of 6.7-9 $\mathrm{m}$ with a mean value of $225 \mathrm{mg} \mathrm{l}^{-1}$. At top $1.5 \mathrm{~m}$, each of the profiles quickly reaches a maximum concentration of between 300 and $600 \mathrm{mg} \mathrm{l}^{-1}$. Such a peak concentration is typical in many chloride profiles in arid regions and indicates either a net infiltration rate that has changed over time, significant nonpiston flow, or a combination of these two processes.

The main recharge estimates and residence times are summarized for the two areas (Suhete and Badain Jilinmiao) in Table 1. Values of chloride in rainfall used are $1.5 \mathrm{mg} \mathrm{l}^{-1}$ and the mean annual rainfall of $89 \mathrm{~mm}$. The use of constant chloride flux of $133.5 \mathrm{mg}$ $\mathrm{m}^{-2}$ year ${ }^{-1}$ in the chloride age calculations is a simplification of the total deposition corresponding to likely changes in environmental and climate conditions over the last 2,000 years. The higher chloride value for BB1 (165 $\mathrm{mg} \mathrm{l}^{-1}$ ) corresponds to a lower mean annual recharge of $0.81 \mathrm{~mm}$ year ${ }^{1}$, the record representing a residence time of 1,025 years. For the area of Suhete the recharge rates are $1.05 \mathrm{~mm}_{\text {year }}{ }^{-1}$, the records representing a residence time of 1,660 years. The profile $\mathrm{SH} 2$ as archive of climatic change for periods up to 1,660 years is illustrated in Figure 5 after calibrated using recharge rate and moisture content according the model developed by Cook et al. (1992), subdividing the data according to intervals of high and low chloride. The record is 1,660 years and climatic events of $10-20$ years duration were preserved well in the profile. There are five markedly recharge stages occurred in 500-550, 650750, 850-980, 1280-1400 and 1500-1600 AD. The highest values of recharge rate of $5.0 \mathrm{~mm}$ occurred in the $690 \mathrm{~s}$ $\mathrm{AD}$, and then in the 530, 960 and $1350 \mathrm{AD}$ occurred the higher recharge of 3.16, 2.47 and $3.86 \mathrm{~mm}$ respectively, which obviously indicated the great climatic change. Afterward, the recharge rate decreases dramatically and had been lower than average value except for a few ages since the 19th century. The long-term low recharge rates between 980 and $1280 \mathrm{AD}$ indicated the very drought episodes occurring in the 'Medieval Warm period.'

\section{Groundwater geochemical characteristics}

The total dissolved solid (TDS) contents together with main ions in the groundwater samples collected in the 
Table 1. The estimates of mean annual recharge using chloride for BB1 profile together with $\mathrm{SH} 1, \mathrm{SH} 2$

\begin{tabular}{llllllr}
\hline Profile & $\begin{array}{l}\text { Sampling } \\
\text { interval } \\
(\mathrm{m})\end{array}$ & $\begin{array}{l}\text { Mean } \\
\text { rainfall } \\
(\mathrm{mm})\end{array}$ & $\begin{array}{l}\text { Mean Cl } \\
\text { in rainfall } \\
\left(\mathrm{mg} \mathrm{l}^{-1}\right)\end{array}$ & $\begin{array}{l}\text { Mean Cl } \\
\text { in profile } \\
\left(\mathrm{mg} \mathrm{l}^{-1}\right)\end{array}$ & $\begin{array}{l}\text { Mean } \\
\text { recharge } \\
(\mathrm{mm})\end{array}$ & $\begin{array}{l}\text { Residence } \\
\text { time } \\
(\text { Years })\end{array}$ \\
\hline SH1 & $0-10$ & 89 & 1.5 & 120 & 1.11 & 876 \\
SH2 & $0-20$ & 89 & 1.5 & 127 & 1.05 & 1,660 \\
BB1 & $0-20$ & 89 & 1.5 & 165 & 0.81 & 1,021 \\
\hline
\end{tabular}

Heihe River and Shiyang River Basin are summarized statistically in the Table 2 . The TDS ranged from $293 \mathrm{mg} \mathrm{l}^{-1}$ in piedmont fans of Zhangya to $6,576 \mathrm{mg} \mathrm{l}^{-1}$ in the terminal lake of Ejina Basin, while ranged from $317 \mathrm{mg} \mathrm{l}^{-1}$ in piedmont fans of Wuwei to $8,097 \mathrm{mg} \mathrm{l}^{-1}$ in the terminal lake of Minqin Basin in the Shiyang River. It is clear that the groundwater salinity increase from south to north in the direction of groundwater flow in both catchments. The groundwater in the middle reach belong to fresh water, while the lower reach is Brackish water both in Heihe River and Shiyang River Basin. The plot of chemical analyzes on a trilinear diagram of groundwater in Heihe River together with Shiyang River (Figure 6) shows that a majority of the groundwater samples are of bicarbonate type in the Zhangye Basin and Wuwei Basin, and sulphate type in the Ejina Basin and Minqin Basin, and a number of samples fall in the 'no-dominant' class in the anion facies, while some shallow groundwater samples from the terminal lakes of the both river basin are of chloride type. Among the cation facies, the majority of the water samples fall in the class of 'no-dominant' type, but some of samples in the Wuwei Basin are of calcium type and in the terminal lake are of sodium or potassium type. Overall, the trilinear diagram shows that groundwater regionally are of alkali-sulphate type in the recharge area, changing to alkali-sulphate-chloride type along the groundwater flow direction and finally becoming sodium chloride type at the terminal lake. The sequence of cation dominance in groundwater of the Quaternary aquifer in Heihe River has the order: $\mathrm{Mg}^{2+}>\mathrm{Ca}^{2+}>\mathrm{Na}^{+}>$ $\mathrm{K}^{+}$in the upper reach and $\mathrm{Na}^{+}>\mathrm{Mg}^{2+}>\mathrm{Ca}^{2+}>\mathrm{K}^{+}$in the Lower reach, whilst the sequence of anion dominance has the order: $\mathrm{HCO}_{3}^{-}>\mathrm{SO}_{4}^{2-}>\mathrm{Cl}^{-}$in the south basin, $\mathrm{SO}_{4}^{2-}>\mathrm{HCO}_{3}^{-}>\mathrm{Cl}^{-}$the middle part and $\mathrm{SO}_{4}^{2-}>$ $\mathrm{Cl}^{-}>\mathrm{HCO}_{3}^{-}$in the north basin. The sequence of anion dominance in groundwater of the quaternary aquifer in the Shiyang River has the order: $\mathrm{HCO}_{3}^{-}>\mathrm{SO}_{4}^{2-}>\mathrm{Cl}^{-}$ in the south basin (Wuwei), and $\mathrm{SO}_{4}^{2-}>\mathrm{Cl}^{-}>\mathrm{HCO}_{3}^{-}$in the north basin (Minqin). The sequence of cation dominance has the order: $\mathrm{Ca}^{2+}>\mathrm{Mg}^{2+}>\mathrm{Na}^{+}>\mathrm{K}^{+}$in the $\mathrm{Wu}-$ wei Basin and $\mathrm{Na}^{+}>\mathrm{Ca}^{2+}>\mathrm{Mg}^{2+}>\mathrm{K}^{+}$in the Minqin. One significant characteristic of the groundwaters is the very low $\mathrm{mK} / \mathrm{Na}$ ratio of 0.017 , which would denote the dominance of albite over K-feldspars in the catchment

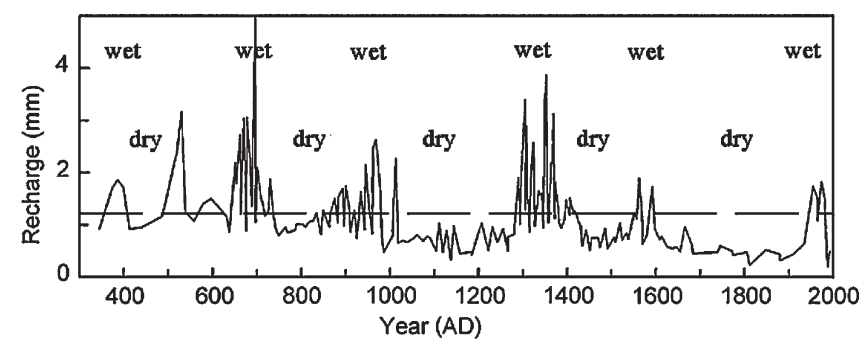

Figure 5. The recharge history and the climatic record information from unsaturated zone profiles

area. The $\mathrm{mNa} / \mathrm{Cl}$ ratio in the aquifer of Heihe Basin are variety between 0.64 and 3.85 and most of them are over 2, in the aquifer of Shiyang Basin are variety between 0.59 and 3.3 and most of them are over 1.5. The $\mathrm{mNa} / \mathrm{Ca}$ has an increasing trend along the groundwater flow from 1 to more than 8 in Heihe River and from 0.2 to more than 24 in Shiyang River. Both ratios indicating the reaction of silicate minerals and or some cation exchange is occurring at the expense of some cation. Saturation indices (Shi and Ma 2004) are just below saturation with calcite which underlines the mainly continental character of the aquifer and suggests the virtual absence of carbonate and with silicate weathering being the dominant process. The groundwaters are also close to dolomite saturation and this reflects the $\mathrm{mMg} / \mathrm{Ca}$ ratios close to 1, with $\mathrm{Mg}^{2+}$ dominant over $\mathrm{Ca}^{2+}$. This may be explained by the weathering of fresh, reactive mafic minerals in the sediments derived from diorites in the Qilian Shan source rocks.

\section{Recharge environment and groundwater age}

\section{Stable isotopes}

Precipitation data are available for several meteorological stations around the study area, which was statistically summarized in the Table 3, although chemical data are not generally available. Data taken from the Global Network of Isotopes in Precipitation (GNIP) database, the International Atomic Energy Agency (IAEA) from 1985 to 2001, were used and are compared to the global meteoric water line (GMWL) (Craig 1961). Values of deuterium $\left(\delta^{2} \mathrm{H}\right)$ and oxygen-18 $\left(\delta^{18} \mathrm{O}\right)$ in precipi- 
Table 2. The statistics of the TDS together with main Ions concentration in the groundwater samples in the Heihe River Basin (Zhangye and Ejina) and Shiyang River Basin (Wuwei and Minqin) ( $\mathrm{mg} \mathrm{l}^{-1}$ )

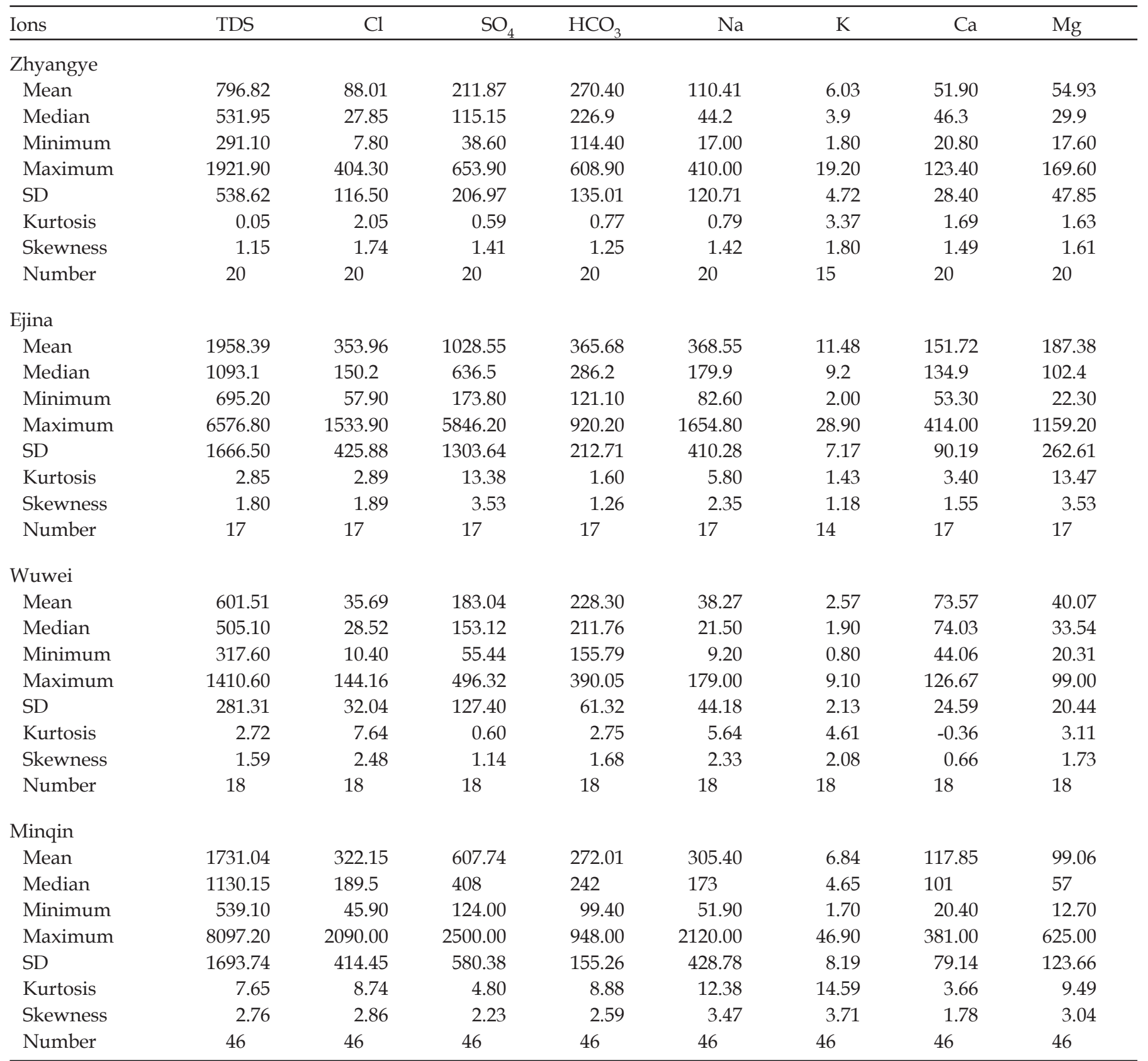

tation vary over a large range from -236.50 to $45.5 \%$ and -39.5 to $3.9 \%$ respectively, but the local line is quite similar to the GMWL with an equation of $\delta^{2} \mathrm{H}=7.56 \delta^{18} \mathrm{O}+$ 5.05 and an $r^{2}$ of 0.97 (Figure 7). The local line reflects only slight enrichment in moisture due to evaporation of the monsoon air mass. The weighted mean rainfall values at Zhangye station for seven non-consecutive years between 1986 and 1996 and all except one set of data plot on or close to the meteoric line with an overall mean composition of $\delta^{18} \mathrm{O}-6.51 \%$ and $\delta^{2} \mathrm{H}-43.9 \%$. This value, indicative of the heaviest rains, is most likely to be representative of present day local recharge. The groundwaters in Zhangye basin and Ejina of the Heihe River show a range from -40.6 to $-62.5 \% \delta^{2} \mathrm{H}$ and -1.7 to $-10.2 \%$ o $\delta^{18} \mathrm{O}$. The deep groundwaters in Zhangye Basin has the same isotopic composition with that in Minqin. The $\delta^{2} \mathrm{H}$ and $\delta^{18} \mathrm{O}$ values of the deep groundwaters is significantly lighter than the shallow waters both in the Zhangye Basin and Ejina Basin, which were slightly enriched in the heavy isotopes and has an intercept on the GMWL in the domain of modern rainfall $\left(-7 \%\right.$ o $\left.\delta^{18} \mathrm{O}\right)$. It is concluded that the deeper waters in both rivers are palaeowaters and that the shallower water with values between -7 and $-11 \%$ o $\delta^{18} \mathrm{O}$ represent 


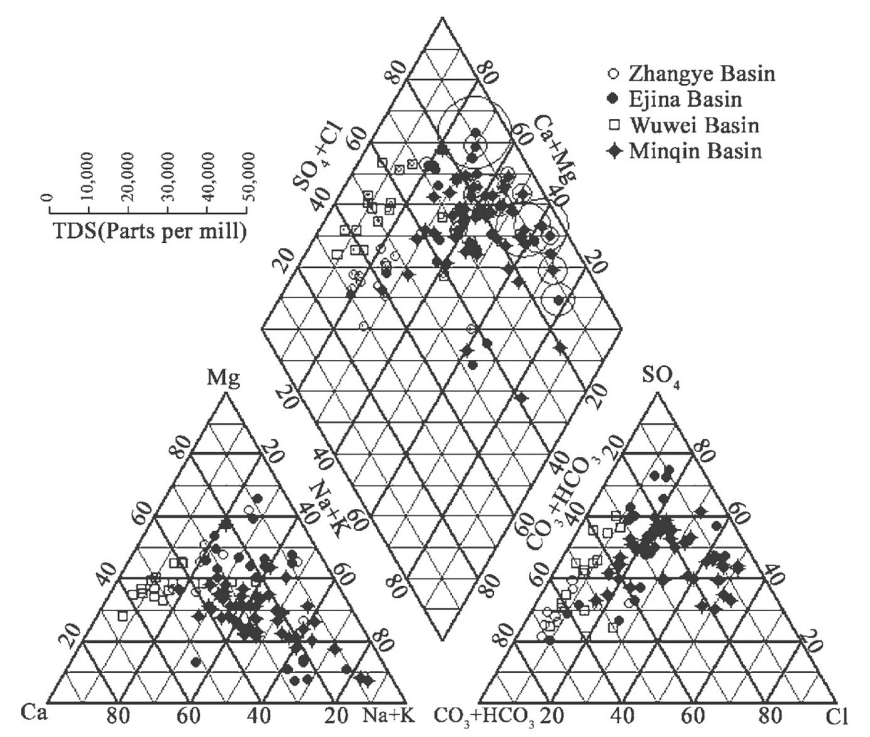

Figure 6. Piper plot of chemical analysis of groundwater samples collected from the Quaternary aquifer in the Heihe River and Shiyang River

mainly palaeowaters mixed with limited modern recharge. The groundwaters in Minqin Basin of the Shiyang River show a range from -31.6 to $73.8 \%$ o $\delta^{2} \mathrm{H}$ and -7.14 to $-11.54 \%$ o $\delta^{18} \mathrm{O}$. The deeper groundwaters (from depths of 200-320 m) found mainly in the north of the basin generally have the lightest isotopic compositions of -9.38 to $-10.65 \%$ o $\delta^{18} \mathrm{O}$, but this is not always the case; lighter waters are found at two wells at 60-120 m depth near the south of the basin. In addition one shallow well has a strongly depleted composition and another shows evaporation from an isotopically light source. The initial interpretation of these data is that there is likely to be a component of palaeowater-derived irrigation water. Some, but not all, of the heavier intermediate depth groundwaters (-7 to $-8 \%$ o $\left.\delta^{18} \mathrm{O}\right)$ lie close to the main bifurcation of the Shiyang River around Minqin implying that the river source may also have been an important source of recharge in the past. The isotopic composition of the lakes and the shallow groundwaters feeding the lakes in the Baddain Jaran Desert show strong evaporation and are interrelated along a line that intercepts the local meteoric line at around $-12 \%$ o $\delta^{18} \mathrm{O}$ (Figure 7). This implies that the groundwaters and the lakes in the desert are genetically related and that these are unrelated to modern recharge which has a weighted mean value lighter by some $5 \%$ o $\delta^{18} \mathrm{O}$. The lakes and inflowing groundwaters therefore originate as palaeowaters formed under a cooler climate and/or to a remote source rather than modern recharge. In this context it is noted that the weighted mean composition of modern high altitude precipitation at Lhasa is $13.7 \%$ o $\delta^{18} \mathrm{O}$. Whist the unsaturated zone moisture is strongly enriched iso- topic signatures, intercepting the GWML around $-6 \%$ $\delta^{18} \mathrm{O}$ and has an indicative of modern recharge.

\section{Tritium}

Tritium has been used in many groundwater studies to determine the residence time of groundwaters. Once ${ }^{3} \mathrm{H}$ enters the subsurface as meteoric water, it becomes isolated from the influences of variable atmospheric ${ }^{3} \mathrm{H}$ concentrations. Concentrations of ${ }^{3} \mathrm{H}$ in the groundwater system depend primarily on the initial atmospheric concentration at the time of recharge and the radiogenic decay that has occurred since infiltration. In some cases, investigators have interpreted approximate groundwater ages from ${ }^{3} \mathrm{H}$ concentrations. This requires that the initial precipitation ${ }^{3} \mathrm{H}$ input record be known in order to interpreted quantitatively the groundwater age from the pattern of ${ }^{3} \mathrm{H}$ concentrations along the groundwater flow path. In main regions of the world however, ${ }^{3} \mathrm{H}$ precipitation data is not locally available. It is necessary in this case to extrapolate data from more distant locations. The IAEA's network of pluviometer in Zhangye is the only station in the north China that can provide the monthly precipitation ${ }^{3} \mathrm{H}$ concentrations from 1983. However, detailed data are not available in these regions before 1983. In order to infer what the historic distribution of ${ }^{3} \mathrm{H}$ has been in precipitation in the region, it is necessary to reconstruct the data. IAEA ${ }^{3} \mathrm{H}$ data are abundant in the Hong Kong Station. Wei et al. (1980) has developed the detail models for reconstructing ${ }^{3} \mathrm{H}$ concentration in precipitation according to the linear relationship in ${ }^{3} \mathrm{H}$ with both increasing latitude and increasing distance from Hong Kong. In different latitude the ${ }^{3} \mathrm{H}$ has the different relationship with annual precipitation. Guan (1986) has test the model with ${ }^{3} \mathrm{H}$ records in several pluviometers. According to the model, the ${ }^{3} \mathrm{H}$ data has been reconstructed from 1953 to 1982 in the Zhangye station and used as the local ${ }^{3} \mathrm{H}$ data (Figure 8). The reconstructed maximum peak was reaching $2,100 \mathrm{TU}$ in 1963, which is lower than the tritium peak value of 3,280 TU in Vienna, but quite higher than the average tritium value of 600 TU in Hong Kong. The reconstructed ${ }^{3} \mathrm{H}$ value is about $110-150$ TU during the 1970s, which has good relation with ${ }^{3} \mathrm{H}$ record precipitation value of 110-180 TU observated by Wei et al. (1980) in the Mongolia Plateau. In order to make use of ${ }^{3} \mathrm{H}$ as a groundwater tracer in the region to estimate approximate groundwater age, the precipitation ${ }^{3} \mathrm{H}$ record must be modified to reflect the mass loss through radioactive decay. This can be done using a basic exponential decay equation using a half life for ${ }^{3} \mathrm{H}$ of 12.43 years. The decayed precipitation record, which would represent ${ }^{3} \mathrm{H}$ concentration in groundwater that had infiltrated between 1957 and 1996 is shown in Figure 9. This 


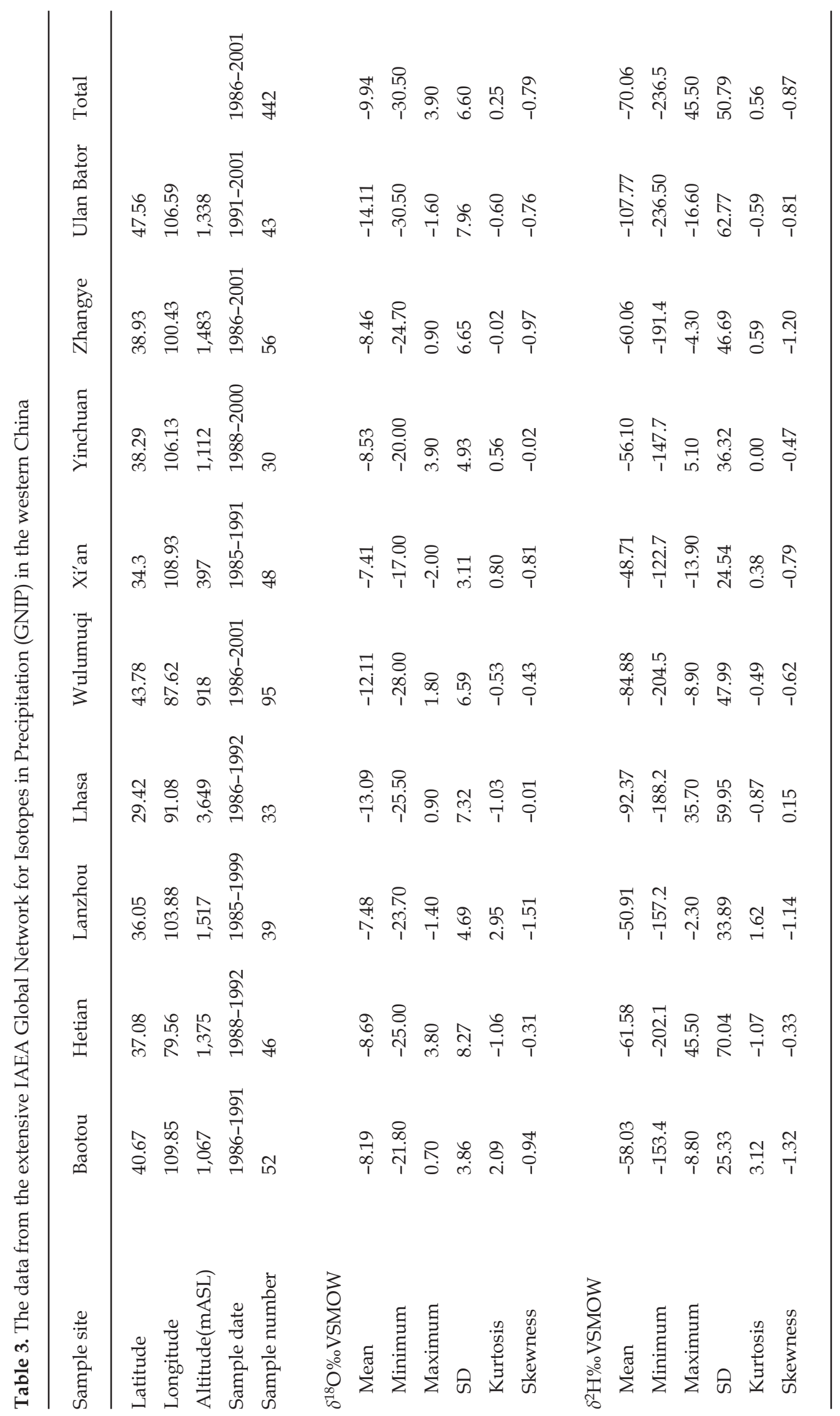




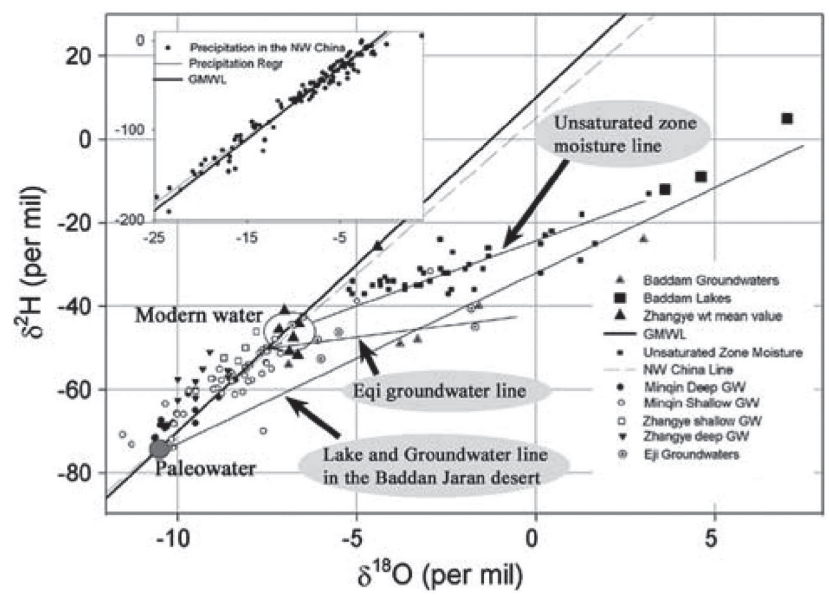

Figure 7. Stable isotope rations in the groundwaters of the Shiyang River, Heihe River and Baddain Jaran Desert and surrounding area together with mean annual rainfall for Zhangye station

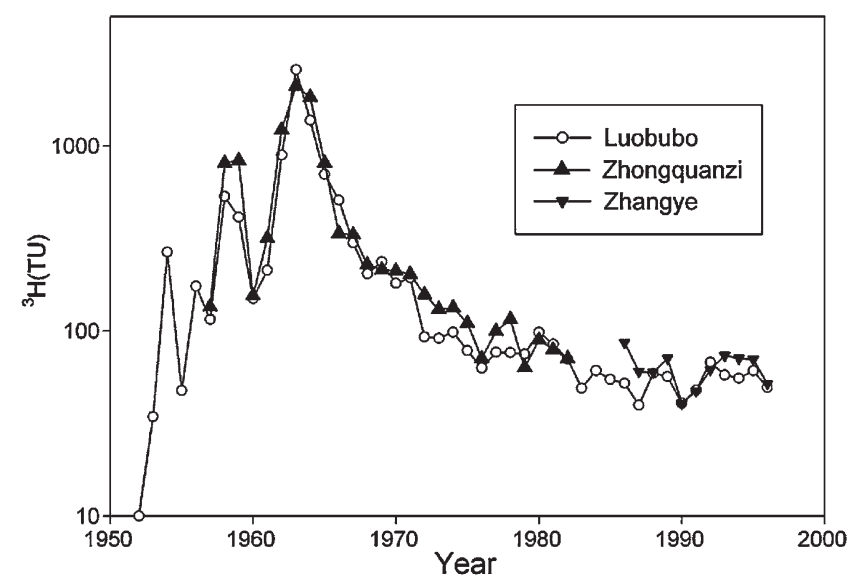

Figure 8. The reconstructed tritium value from 1953 to 1982 in the Zhangye station with a plot of observation data from 1983

groundwater ${ }^{3} \mathrm{H}$ record now can be used assist in the interpretation of the regional groundwater flow system in the Mongolia Plateau.

However, age determinations accurate to the year are impossible and of no meaning to groundwater studies in the region according to the Figure 9. For example, a groundwater with a ${ }^{3} \mathrm{H}$ value of $30-35$ TU was possibly recharged by the precipitation in any of the 8 years: 1968-1971, 1986, 1989, 1992 and 1996. In addition, complicated mixing takes place in each aquifer, and the mode and extent of mixing of each year's recharge with that of previous years recharge is unknown. However, semi quantitative dating is possible and very informative. Groundwater with no more than 0.5 TU tritium has a pre-1952 age. Groundwater with significant tritium concentration (more than $10 \mathrm{TU}$ ) is of post 1957 age. In this case, only 5 years the left tritium may less than 20 TU. From the overall trend it is obviously concluded that

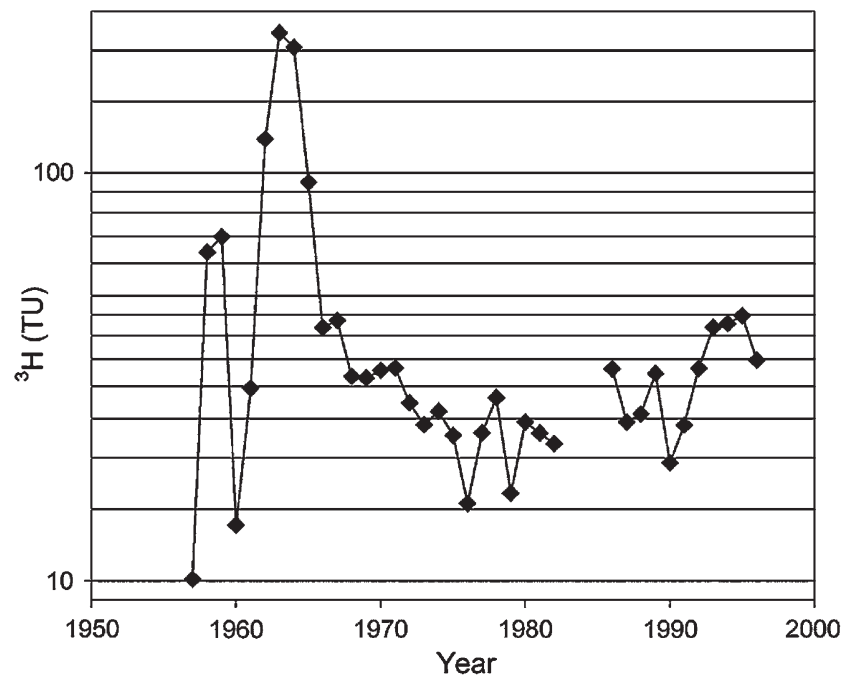

Figure 9. The decayed precipitation record of ${ }^{3} \mathrm{H}$ concentration in groundwater that had infiltrated between 1957 and 1996

groundwater with a post 1957 age should have the tritium concentration more than $20 \mathrm{TU}$. It is obvious that the majority groundwater collected by Chen et al. (2003) in the Baddain Jaran Desert and Heihe River has the ${ }^{3} \mathrm{H}$ values less than $10 \mathrm{TU}$, and only five spring water sample in the Lonshoushan Mountain and western part of the Baddain Jaran Desert has the tritium value of 20-30 TU, indicative of the pre-1957 ages. It is challenged that Chen et al. (2003) have given an incomplete and misleading interpretation of the isotopic data combined with an absence of hydrogeological conceptualization. Hence, the conclusion of modern deep groundwater flowing from the Qilian Mountains to the Badain Jaran Desert is unsound. The spring flow in the Badain Jaran Desert recorded by Chen et al. (2003) is likely to be maintained by palaeowater rather than modern snowmelt. Radiocarbon data are required to confirm the hydrogeological model implied by isotopic data, but analogous results from a series study in Arid Northern China (Chen et al. 2003), the Minqin Basin (Zhang et al. 2000; Ma et al. 2005; Edmunds et al. 2006), the Ejina area (Wu et al. 2001) and Zhangye Basin (Zhang et al. 2005) confirmed that the deeper groundwaters have late Pleistocene ages except where recharged by modern river runoff.

\section{Conclusion}

Chloride has the advantage of simple analysis and of being conserved during the recharge process so that a mass balance approach can be used. A mean value of 1 $\mathrm{mm}$ year- $^{-1}$ for the three profiles based on CMB was estimated. The Pilot studies have tested the feasibility of investigating the unsaturated zone as an archive of climatic and palaeoenvironmental information. The results 
indicate that an archive spanning hundreds to thousands of year may exist in the fine-grinned sand deposits in NW China, which has a resolution at decadal scale. Overall the groundwater quality is good for drinking and irrigation in both rivers. The TDS and the major ions in groundwater increases sharply down stream from the debouchure, more than $1,000 \mathrm{mg} \mathrm{l}^{-1}$ TDS in the lower reaches both in the Heihe and Shiyang Rivers. Groundwater in the mountainous regions and the piedoment alluvial-diluvial fans is in $\mathrm{HCO}_{3}^{-}$type with a low mineralization. The mineralization of groundwater in the basins in the lower reaches increases further and the type of $\mathrm{Cl}^{-}-\mathrm{SO}_{4}^{2-}$ is dominant. Stable isotopes $\left(\delta^{18} \mathrm{O}\right.$ and $\left.\delta^{2} \mathrm{H}\right)$ provide clear distinction between modern and ancient waters. A good rainfall database from nearby Zhangye provides definition of the composition of modern rainfall. The signature of groundwater from the late Pleistocene differs markedly from that of the Holocene, shown clearly by the stable isotopic compositions (around $-10.5 \%$ o $\delta^{18} \mathrm{O}$ as compared with values of $-7 \%$ at the present day). This primary difference is similar to that observed by Chen et al. (2003) for the North China Plain near Beijing. These authors also show a progressive enrichment in $\delta^{18} \mathrm{O}$ values from about $7 \mathrm{ka}$ $\mathrm{BP}$ and an optimum around 6-4 ka BP equivalent to the global warming and a strengthened monsoon. It is clear that tritium age determinations accurate to the year are impossible and of no meaning to groundwater studies in the region due to tritium measurements in the shallow unconfined groundwater environment could either be influenced by vapour exchange with the soil atmosphere or an expression very localized modern recharge. In addition, complicated mixing takes place in each aquifer, and the mode and extent of mixing of each year's recharge with that of previous years recharge is unknown. A tritium value in the groundwater means multiple recharge ages in this region. It is challenged that Chen et al. (2004) given an incomplete and misleading interpretation of the tritium age. Our results clearly show that modern direct recharge in this area is negligible. In addition it is apparent that the groundwaters being abstracted in the Minqin Basin, Ejina Basin and feeding the lake system of the Badain Jaran are part of a regional flow network related to a wetter past climate as source of recharge. This system is largely decoupled from the river network in this area. The recharge source in the past and to a limited extent in the more arid conditions of the present day included the foothills of the mountains of the Tibetan Plateau. In the Badain Jaran, without any further development it is apparent that following the aridity of the late Holocene groundwater levels are likely to decline further and the lake ecosystem is under threat from purely natural causes. The main concern is that the valuable groundwater derived from cli- mates of the past must now as a matter of urgency is better managed as a strategic water resource, not least to maintain the unique and fragile desert ecosystems.

Acknowledgments - The research is supported by the National Science Foundation of China (No. 40671029), the NSFC Innovation Team Project (No. 40421101) and the Program for New Century Excellent Talents in University (NCET). This work also forms part of 111 project (No. B06026) and a wider UK-China collaboration. We thank Xianghu Li and Tianming Huang for the field works and laboratory analysis. Sincere thanks are extended to Professor Fahu Chen and W. M. Edmunds for collaboration. We also appreciate the contributions of anonymous reviewers for Environmental Geology for improving the manuscript.

\section{References}

Allison, G.B., Hughes, M.W. (1978) The use of environmental chloride and tritium to estimate total recharge to an unconfined aquifer. Aust J Soil Res 16: 181-195.

Allison, G.B., Gee, G.W., Tyler, S.W. (1994) Vadose zone techniques for estimating groundwater recharge in add and semi-regions. Soil Sci Soc Am J 58: 6-14.

Chen, J.S., Fan, Z., Wang, J., Gu, W., Zhao, X. (2003) Isotope methods for studying the replenishment of the lakes and downstream groundwater in the Badain Jaran Desert. Acta Geosci Sin 24(6): 497-504.

Chen, J.S., Li, L., Wang, J. (2004) Major desert groundwater resource maintains the world's highest stationary sand dunes. Nature 432: 459.

Chen, Z., Qi, J., Xu, J., Ye, H. (2003) Palaeoclimatic interpretation of the past $30 \mathrm{kyr}$ from isotopic studies of the deep confined aquifer of the North China Plain. Appl Geochem 18: 997-1,009.

Cook, P.G., Edmunds, W.M., Gaye, C.B. (1992) Estimating paleorecharge and paleoclimate from unsatured zone profiles. Water Resour Res 28: 2,721-2,731.

Craig, H. (1961) Isotopic variations in meteoric waters. Science 133: 1,702-1,703.

Ding, H.W., Yao, X.R., Yan, C.Y., Chen, X.Y. (2002) Orientation of water seeking in the area of water shortage located in Qilianshan Mountain Pediment of Hexi Corridor. J Hydrogeol Eng Geol 29(6): 17-34.

Edmunds, W.M., Darling, W.G., Kinniburgh, D.G. (1988) Solute profile techniques for recharge in semi-arid and arid terrain. In: Simmers I (editor). Estimation of Natural Groundwater Recharge, NATO ASI Series C222. Reidel, Dordrecht, p. 139-158.

Edmunds, W.M., Guendouz, A.H., Mamou, A., Moulla, A.S., Shand, P., Zouari, K. (2003) Groundwater evolution in the Continental Intercalaire aquifer of southern Algeria and Tunisia: trace element and isotopic indicators. Appl Geochem 18: 805-822. 
Edmunds, W.M., Ma, J., Aeschbach-Hertig, W., Kipfer, R., Darbyshire, D.P.F. (2006) Groundwater recharge history and hydrogeochemical evolution in the Minqin Basin, North West China. Appl Geochem 21: 2,148-2,170.

Feng, Q., Qiu, Y.G., Cheng, G.D. (1997) The problems and countermeasures of water resources in arid northwest China. Adv Earth Sci 12: 33-39 (in Chinese).

Feng, Q., Liu, W., Su, Y.H., Zhang, Y.W., Si, J.H. (2004) Distribution and evolution of water chemistry in Heihe River Basin. Environ Geol 45: 947-956.

Gee, G.W., Wieringa, P.J., Andraski, B.J. (1994) Variations in water balance and recharge potential at three western desert sites. Soil Sci Soc Am J 58: 63-72.

Guan, B. (1986) The extrapolation of tritium in the precipitation of China. J Hydrogeol Eng Geol 4: 38-42.

Harrison, T.M., Copeland, P., Kidd, W.S.F., An, Y. (1992) Raising Tibet. Science 255: 1,663-1,670.

Hofmann, J. (1996) The lakes in the SE part of Badain Jaran Shamo, their limnology and geochemistry. Geowissenschaften 7/8: 275-278.

Li, J.J., Wen, S., Zhan, Q. (1979) Study on the times, extent and form of Tibet Plateau upheaving. Sci China 9: 608-616.

Li, P.C., Feng, G.Z. (1997) Study of the principles of support for water resource sustainability and water economical utilization. Agric Res over Arid Area 15: 1-7.

Ma, J.Z., Edmunds, W.M. (2006) Groundwater and lake evolution in the Badain Jaran Desert ecosystem, Inner Mongolia. Hydrogeol J 14: 1,231-1,243.

Ma, J.Z., Wang, X.S., Edmunds, W.M. (2005) The characteristics of groundwater resources and their changes under the impacts of human activity in the arid North-West Chinaa case study of the Shiyang River Basin. J Arid Environ 61: 277-295.
Molner, P., Tapponnier, P. (1975) Cenozoic tectonic of Asia: effects of a continental collision. Science 189: 419-426.

Shi, J.I., Wang, Q., Shen, G.J., Wang, G.Y., Zhang, Z.N. (2001) Isotope geochemistry of the groundwater system in arid and semi-arid systems and its significance; a case study in the Shiyang River Basin, Gansu Province, north west China. Environ Geol 40: 557-565.

Shi, P., Ma, J.Z. (2004) Geochemistry modelling of groundwater beneath Minqin Basin. Arid Land Geogr 27(3): 305-309.

Shi, Y., Zhang, X. (1995) The influence of climate changes on the water resources in the arid areas of northwest China. Sci China B 25: 968-977.

Tyler, S.W., Chapman, J.B., Conrad, S.H., Hammermeister, D.P., Blout, D.O. (1996) Soil water flux in the southern great basin, United States: temporal and spatial variations over the last 120,000 years. Water Resour Res 32(6): $1,481-1,499$.

Wei, K.Q., Lin, R.J., Wang, Z.X. (1980) The tritium distribution in the natural water in the China. Chin Sci Bull 25(10): 467-470.

Wu, X. (1999) The status of hydrogeological research in arid and semiarid zone. J Hydrogeol Eng Geol 4: 41-46.

Wu, X., Shi, S., Li, Z.H. (2001) The study on the groundwater flow system in the Ejina Basin, the lower reach of Heihe River. J Hydrogeol Eng Geol 2: 30-33.

Zhang, H.C., Ma, Y., Wunnemann, B., Pachur, H.-J. (2000) A Holocene climatic record from arid northwestern China. Palaeogeogr Palaeoclimatol Palaeoecol 162: 389-401.

Zhang, J., Lin, Z. (1992) Climate of China. Wiley, New York.

Zhang, Y.H., Wu, Y., Su, J., Wen, X., Liu, F. (2005) Groundwater replenishment analysis by using natural isotopes in Ejina Basin, northwestern China. Environ Geol 48: 6-14. 